Egyptian Journal of Agronomy

\title{
Can the Productivity of Wheat (Triticum sativum) Grown under Calcareous Soil Condition Be Increased by Modifying the Crop Fertilizers Recommendation?
}

\author{
A.B. El-Nasharty, E.A.A. Abou El-Nour ${ }^{\#}$, M.M. El-Fouly \\ Fertilization Technology Department, Institute for Agricultural and Biological \\ Research, National Research Centre. 12622. Dokki, Cairo, Egypt.
}

\begin{abstract}
$\mathbf{T}$ WO field experiments were conducted in Oraby village, Nubaria Region, El-Behira Governorate, Egypt, during the two winter seasons of 2014 and 2015 to explore the best fertilizer recommendation for wheat (Triticum sativum) ,c.v. Giza 168 grown under calcareous soil since the productivity of wheat is very low when cultivated under such soil conditions. Seven NPK treatments were applied. Results indicated that all NPK treatments showed positive effects on all studied parameters as compared with either negative (no added fertilizers) or positive (farmer fertilization) controls. The treatment positive effects takes the descending order of :NPK based on soil type $+\mathrm{MN}>\mathrm{NPK}$ based on soil type $>$ NPK MoA $>$ NK MoA $>$ NP MoA $>$ positive control (Farmer fertilization) $>$ negative control (no added fertilizers). Result also indicated that NPK based on soil type in combination with micronutrient foliar feeding (Balanced fertilization) significantly increased plant nutritional status, grain yield, yield components and grain \& straw nutritional value. Results also proved that fertilizer recommendations should be modified to fit soil conditions for achieving maximum crop productivity.
\end{abstract}

Keywords: Calcareous soil, Wheat, Yield.

\section{Introduction}

Calcareous soils are rich in $\mathrm{CaCO}_{3}$, which tend to be low in organic matter and available nitrogen. Also the presence of $\mathrm{CaCO}_{3}$ affects the availability of $\mathrm{N}, \mathrm{P}, \mathrm{Mg}, \mathrm{K}$ and micronutrients (Fe, Zn, Mn and Cu) (Brady \& Weil, 1999; Wahba et al., 2019). Abdel Aal et al. (1990) stated that these calcareous soils in Egypt reached up to 260.000ha.

In Egypt the fertilizer recommendations issued by the Ministry of Agriculture for various crops are general recommendations, regardless of the regional variation. Therefore, farmers, according to their experience, determine the added fertilizer on their own way (El-Saady et al., 2014).

Recently, there have been many attempts to link fertilizer recommendations with soil testing and plant analysis for optimizing fertilizers use, obtaining high productivity (quantity and quality), reduce costs and preserve the environment. Cereal crops clearly differ between each other in relation to the fertilization rates. Further these application rates of NPK vary among soil types, regions and countries for the same cereal crop (Soh, 1998).

Wheat is one of the most important strategic field crops in Egypt. This crop is also one of the crops that Egypt imports annually to meet the population needs and to reduce the gap arising between production and need. Accordingly, the country is trying to reduce imports by increasing the cultivated area on the one hand and increasing the yield produced per unit area on the other hand. This can be achieved by optimizing nutrients through fertilization. It was found that the addition of nutrients under conditions of intensive agriculture ranges from the extreme wasteful in adding fertilizers to the extreme shortness of the addition; both cases negatively affect humans and the environment (Vitousek et al., 2009). Therefore, the fertilization process

"Corresponding author email: elzanatyabouelnour@gmail.com

Received 25/10/2021; Accepted 05/12/ 2021

DOI: 10.21608/agro.2021.102701.1287

C2021 National Information and Documentation Center (NIDOC) 
must be controlled to that there is a balance and integration in the addition process until we reach the target yield. To achieve this, it must be taken into account during the process of adding fertilizers, choosing the appropriate fertilizer source for soil conditions and sensing the quantities that achieve the desired goal, taking into account the method of addition, and finally the appropriate time for addition (Abou-El Nour \& El-Fouly, 2013; Kumar et al., 2018; Salim \& Raza, 2020). Balanced share of NPK application has great impact on wheat productivity when applied at the proper time (Malghani et al., 2010). They also found that using high yield varieties and the increment in cropping intensity resulted in increasing nutrients depletion from the soil (El-Fouly et al., 2012). Malghani,et al., 2010 reported that by increasing the rate of NPK significant increments in wheat growth and yield as well as its components were achieved.

Soil properties have a direct effect on $\mathrm{P}$ deficiency and low P-use efficiency under calcareous soil conditions, which are dominant in semi-arid regions. Under such soil conditions, Korkmaz, et al., 2009 found that wheat dry matter yield and $\mathrm{P}$ content were markedly increased by increasing $\mathrm{P}$ rates over recommended.

Farmers used to pay attention to the degree of extravagance in adding nitrogen and phosphorous, while not paying attention to the addition of potassium and micro-nutrients, which has a negative effect on crop productivity as well as quality.It is well known that the shortage in one nutrient may limit the intake of another nutrient. So, to reach the maximum crop production farmer should use fertilizers in integrated -balanced way (Zheng et. al., 2017). El-Saady et al. (2014) reported that foliar feeding of micronutrients has become an established procedure in crop production to increase yield and improve the quality of the products. In this connection, shaaban, 2001 pointed out that wheat is sensitive to micronutrient deficiencies. Deficiency in one or more of these nutrients can result in nutrient unbalance. He also added, foliar feeding of these nutrients can correct their deficiencies and stimulate the uptake of the other nutrients.

Therefore, the current study aims to try to reach a modify fertilizer recommendation with nutrients balance for wheat grown in calcareous soils in Nubaria region, Egypt.

\section{Materials and Methods}

Two field experiments were conducted in Oraby village, Nubaria region, El-Behira governorate, Egypt, during the two winter seasons of 2014 and 2015 to explore the best fertilizer recommendation for wheat grown under calcareous soil. Soil was ploughed using a chisel plough, leveled by wooden leveler and divided into treatment units. Plot area was $10.5 \mathrm{~m}^{2}$ ( $3.5 \mathrm{~m}$ long and $3 \mathrm{~m}$ wide). The field experiments were conducted on the same soil and the same experimental unites of the studied treatments. All agronomic practices were done as usual. Wheat (Triticum sativum) grains, cv. Giza 168 were cultivated on 24 and 21 November in the first and second seasons, respectively. The preceding crop was maize (Zea maize).

\section{Treatments}

Treatments studied were as follows:-

1. Negative control (without any fertilizers addition)

2. Positive control (farmer's fertilizers) i.e. 100 $\mathrm{N}: 31 \mathrm{P}_{2} \mathrm{O}_{5}: 0.0 \mathrm{~K} 2 \mathrm{O} \mathrm{kg} / \mathrm{fed}$.

3. MoA recommendation without $\mathrm{K}(\mathrm{N}$ : $\left.\mathrm{P}_{2} \mathrm{O}_{5}: \mathrm{K}_{2} \mathrm{O}\right)$ i.e. $100 \mathrm{~N}: 45 \mathrm{P}_{2} \mathrm{O}_{5}: 0.0 \mathrm{~K}_{2} \mathrm{O} \mathrm{kg} /$ fed.

4. MoA recommendation without $\mathrm{P}(\mathrm{N}$ : $\left.\mathrm{P}_{2} \mathrm{O}_{5}: \mathrm{K}_{2} \mathrm{O}\right)$ i.e. $100 \mathrm{~N}: 0.0 \mathrm{P}_{2} \mathrm{O}_{5}: 24 \mathrm{~K}_{2} \mathrm{O} \mathrm{kg} /$ fed.

5. MoA complete recommendation $(\mathrm{N}$ : $\left.\mathrm{P}_{2} \mathrm{O}_{5}: \mathrm{K}_{2} \mathrm{O}\right)$ i.e. $100 \mathrm{~N}: 45 \mathrm{P}_{2} \mathrm{O}_{5}: 24 \mathrm{~K}_{2} \mathrm{O} \mathrm{kg} /$ fed.

6. Modified recommendation according to soil type $\left(\mathrm{N}: \mathrm{P}_{2} \mathrm{O}_{5}: \mathrm{K}_{2} \mathrm{O}\right)$ i.e. $120 \mathrm{~N}: 45 \mathrm{P}_{2} \mathrm{O}_{5}: 48$ $\mathrm{K}_{2} \mathrm{O} \mathrm{kg} /$ fed.

7. Modified recommendation according to soil type $\left(\mathrm{N}: \mathrm{P}_{2} \mathrm{O}_{5}: \mathrm{K}_{2} \mathrm{O}\right)$ i.e. $120 \mathrm{~N}: 45 \quad \mathrm{P}_{2} \mathrm{O}_{5}: 48$ $\mathrm{K}_{2} \mathrm{O} \mathrm{kg} / \mathrm{fed}$. + micronutrients foliar feeding.

$\mathrm{MoA}=$ Ministry of Agriculture

Nitrogen doses were added in the form of ammonium nitrate $(33.5 \% \mathrm{~N})$, divided into three equal amounts, the first was added at sowing,the second was before the first irrigation and the third was before heading stage.

Phosphorus doses were added in the form of triple super phosphate $\left(45 \% \mathrm{P}_{2} \mathrm{O}_{5}\right)$ during land preparation and before planting.

Potassium doses were added as potassium sulphate $\left(48 \% \mathrm{~K}_{2} \mathrm{O}\right)$ in two equal doses, the first at sowing and the second before the first irrigation.

Micronutrients used as a foliar application twicely at 40 and 60 days (at tillering and before 
heading) after sowing using chelated micronutrient compound (3\% Fe: $3 \% \mathrm{Zn}: 3 \% \mathrm{Mn}$ ) at rate of $1.5 \mathrm{~g} / \mathrm{L}$ water.

\section{Data recorded \\ Chemical analysis \\ Soil testing}

Representative soil samples were taken after soil preparation and before fertilization and after harvest from the experimental site $(0-50 \mathrm{~cm}$ depth) the soil samples were air dried, ground in wooden mortar and passed through a $2 \mathrm{~mm}$ pores sieve for carrying out physical and chemical characteristics. $\mathrm{pH}$ and electric conductivity (EC) using water extract method (1 soil: 2.5 water) method (Jackson, 1973), total calcium carbonate $(\mathrm{CaCO} 3 \%)$ by calcimeter method as described by Alison \& Moodle (1965). Organic matter (O.M\%) content according to Walkely \& Black (1934) using potassium dichromate (Chapman \& Pratt, 1978). Phosphorus was extracted using sodium bicarbonate (Olsen et al., 1954). Potassium, calcium, Magnesium and sodium were extracted using ammonium acetate (Jackson, 1973). Iron, manganese, zinc and copper were extracted using DPTA (Lindsay \& Norvell, 1978).

\section{Plant analysis}

Ten flag leaves ant ten plant samples from each unite area were randomly taken at 75 days from sowing and at harvest, respectively for carrying out plant analysis. The plant material was digested using an acid mixture consisting of nitric, perchloric and sulfuric acids in the ratio of 8:1:1 (v/v), respectively (Chapman \& Pratt, 1978).

Nitrogen $(\mathrm{N})$ was determined in the dry plant material using the boric acid modification described by Ma \& Zuazage (1942), and distillation was done using a Buechi 320-N2- distillation unit. Phosphorus was photometrically determined using the molybdate vanadate method according to Jackson, 1973 Potassium, calcium and sodium were determined using flame photometer (Genway). $\mathrm{Mg}, \mathrm{Fe}, \mathrm{Mn}, \mathrm{Zn}$ and $\mathrm{Cu}$ were determined using the Atomic absorption spectrophotometer (Perkin Elemer 1100 B).

\section{Statistical analysis}

The obtained data were subjected to the analysis of variance of randomized complete block design (RCBD), Every treatment was repeated four times, according to Snedecor \& Cochran (1990) where the means of different treatments were compared using the least significant difference (L.S.D) test at 5\% probability level.

\section{$\underline{\text { Results and Discussion }}$}

\section{Soil characteristics}

Data presented in Tables 1 and 2 show the physical and chemical characteristics of the experimental soil either before wheat sowing or after harvest, respectively. According to the tentative values of soil characteristics and available nutrients concentration by Ankerman \& Large (1974), the soil was highly calcareous, high alkaline in reaction $(\mathrm{pH})$ with low to very low in organic matter and medium E.C. The soil showed low feeding power in their nutrient contents, where, soil $\mathrm{P}$ and $\mathrm{K}$ were low, $\mathrm{Ca}$ was very high. Also, micronutrients show very low contents of $\mathrm{Fe}$ and $\mathrm{Mn}$, low to very low in $\mathrm{Zn}$ and low in $\mathrm{Cu}$.

TABLE 1. Physical and chemical characteristics of soil before sowing

\begin{tabular}{|c|c|c|}
\hline \multirow{2}{*}{ Variable } & \multicolumn{2}{|c|}{ Before sowing } \\
\hline & $2013 / 2014$ & $2014 / 2015$ \\
\hline $\mathrm{pH}$ & 8.6 & 8.5 \\
\hline E.C. $\mathrm{dS} / \mathrm{m}$ & 2.7 & 4.0 \\
\hline $\mathrm{CaCO}_{3} \%$ & 27.6 & 27.1 \\
\hline O.M. \% & 0.7 & 1.1 \\
\hline \multicolumn{3}{|c|}{ (mg/100g soil) } \\
\hline $\mathrm{P}$ & 1.2 & 1.0 \\
\hline K & 14.3 & 15.5 \\
\hline $\mathrm{Ca}$ & 596 & 583 \\
\hline \multicolumn{3}{|c|}{ (mg/ kg soil) } \\
\hline $\mathrm{Fe}$ & 3.78 & 3.66 \\
\hline $\mathrm{Mn}$ & 0.81 & 0.80 \\
\hline $\mathrm{Zn}$ & 0.77 & 0.51 \\
\hline $\mathrm{Cu}$ & 0.54 & 0.58 \\
\hline
\end{tabular}

TABLE 2. Physical and chemical characteristics of soil after harvest

\begin{tabular}{lcc}
\hline \multirow{2}{*}{ Variable } & \multicolumn{2}{c}{ After harvest } \\
\cline { 2 - 3 } & $\mathbf{2 0 1 3 / 2 0 1 4}$ & $\mathbf{2 0 1 4} / \mathbf{2 0 1 5}$ \\
\hline $\mathrm{pH}$ & 8.7 & 8.5 \\
$\mathrm{E} . \mathrm{C} . \mathrm{dS} / \mathrm{m}$ & 3.8 & 3.8 \\
$\mathrm{CaCO}$ \% & 27.6 & 27.2 \\
$\mathrm{O} . \mathrm{M} . \%$ & 1.2 & 1.3 \\
\hline \multicolumn{3}{c}{$\mathbf{( \mathbf { m g } / \mathbf { 1 0 0 g } \text { soil) }}$} \\
\hline $\mathrm{P}$ & 1.1 & 0.7 \\
$\mathrm{~K}$ & 15.3 & 15.3 \\
$\mathrm{Ca}$ & 595 & 559 \\
\hline \multicolumn{3}{c}{$\mathbf{( \mathbf { m g } / \mathbf { ~ k g } \text { soil) }}$} \\
\hline $\mathrm{Fe}$ & 3.7 & 3.6 \\
$\mathrm{Mn}$ & 0.88 & 0.81 \\
$\mathrm{Zn}$ & 0.72 & 0.70 \\
$\mathrm{Cu}$ & 0.55 & 0.60 \\
\hline
\end{tabular}




\section{Nutritional status}

Data presented in Table 3 show the nutritional status of wheat plants as a result of different NPK levels and balanced fertilization. Results revealed that all studied treatments significantly increased nitrogen, potassium, iron, manganese and zinc in the flag leaf of wheat as compared with either negative (no added fertilizers) or positive control (farmer fertilization). The highest values of the aforementioned nutrient were achieved by the balanced fertilization treatment $(120 \mathrm{~kg} \mathrm{~N}, 45 \mathrm{~kg}$ $\mathrm{P}_{2} \mathrm{O}_{5}, 48 \mathrm{~kg} \mathrm{~K} \mathrm{~K}_{2} \mathrm{O} /$ fed. in combination with two times foliar feeding with chelated micronutrient compound).

The increment in nitrogen and potassium contents ranged between 21-114 and 19-68\% in the first season, and between 26- 119 and 4 $65 \%$ in the second, respectively as compared with negative control (no added fertilizers). These increments ranged between 6-76 and1041 in the first season and between 6-74 and 26$58 \%$ in the second, respectively as compared with positive control (farmer fertilization). The highest increments achieved by NPK based on soil type $+\mathrm{MN}$ foliar feeding treatment. The same trend was found in both seasons concerning micronutrient contents ( $\mathrm{Fe}, \mathrm{Mn}$ and $\mathrm{Zn})$. These results showed that fertilizer management in case of the very high level of $\mathrm{CaCO}_{3}$ is different from that of low $\mathrm{CaCO}_{3}$. The reason is the effect of soil $\mathrm{pH}$ on soil nutrients availability and chemical reactions that affect the loss or fixation of nutrients. Also, $\mathrm{CaCO} 3$ directly or indirectly affects the availability of essential macro and micronutrients. On the other hand, foliar feeding of a nutrient promotes root growth and thus, the absorption of the nutrients (El-Fouly \& El-Sayed, 1997). Also, Duncan et al. (2018a, b) found that application of balanced fertilization (NPK) increased root length and total root biomass which showed positive impact on nutrient absorption as compared with those received $\mathrm{N}$ fertilizer alone or no added fertilizers.

\section{Yield and its components}

Table 4 shows the effect of different levels of NPK and balanced fertilization on wheat yield and its components during the two growing seasons. Significant positive effects on grain yield, biological yield, harvest index, spike No. $/ \mathrm{m}^{2}$, spikelets No./spike, spike length, 100 grain weight and plant height were recorded as compared with either negative (no added fertilizers) or positive (farmer fertilization) control treatments. The highest positive effects on the aforementioned parameters were achieved by the addition of NPK based on soil type in combination with micronutrients foliar spray treatment (balanced fertilization). The treatment positive effects take the order of :NPK based on soil type $+\mathrm{MN}>\mathrm{NPK}$ based on soil type $>$ NPK MoA $>$ NK MoA $>$ NP MoA $>$ positive control (Farmer fertilization) $>$ negative control (no added fertilizers). The obtained results are in harmony with those of El-Fouly et al. (2012) on maize and El-Saady et al. (2014) on groundnut, who found that in order to achieve high crop productivity and quality, fertilizer required must be in balanced form. This can be achieved through carrying out modification in the recommended fertilizer rates according to soil testing to face the expected problems. Also, applying a balanced fertilization leads to increasing soil fertility, through recovering the depleted soil nutrients by plants.

Data presented in Table 5 show the effect of different NPK levels and balanced fertilization on grain- $\mathrm{N}, \mathrm{K}$, protein, $\mathrm{Fe}, \mathrm{Mn}$ and $\mathrm{Zn}$ concentrations . As compared with the negative control (no added fertilizers) the recorded results showed marked increments in the aforementioned nutrients. The increments in grain- $\mathrm{N}$ and $\mathrm{K}$ concentrations ranged between $8-40 \%$ and $5-38 \%$ in the first season, respectively. While in the second, the increments were ranged between $10-41 \%$ and 7 $46 \%$, respectively. However, when comparing with the positive control (farmer fertilization) the increments were ranged between $4-30 \%$; 6-26\% and $5-31 \% ; 6-36 \%$ for grain $\mathrm{N}$ and $\mathrm{K}$ in the first and second season, respectively. The highest increments recorded in both season were achieved as a result of applying modification on NPK based on soil type in combination with micronutrients foliar feeding (balanced fertilization).

The grain micronutrients i.e. Fe, $\mathrm{Mn}$ and $\mathrm{Zn}$ showed the same trend. The examined treatments follow the descending order of: NPK based on soil type + MN $>$ NPK based on soil type $>$ NPK MoA $>$ NK MoA $>$ NP MoA $>$ positive control (Farmer fertilization) $>$ negative control (no added fertilizers). The increments in nutrients measured in wheat graigs as a result of applying balanced fertilization support the findings of Salim \& Raza (2020) who reported that the shortage of one essential nutrient may limit thje intake of another nutrient. 
TABLE 3. Nutrient concentrations in flag leaf of wheat (Triticum sativum) as affected by different NPK levels and balanced fertilization

\begin{tabular}{|c|c|c|c|c|c|}
\hline \multirow{2}{*}{ Treatment } & \multicolumn{2}{|c|}{$\%$} & \multicolumn{3}{|c|}{ ppm } \\
\hline & $\mathbf{N}$ & $\mathbf{K}$ & $\mathrm{Fe}$ & Mn & Zn \\
\hline \multicolumn{6}{|c|}{ First season $(2013 / 2014)$} \\
\hline Control (No added fertilizers) & 1.54 & 1.90 & 63.7 & 12.7 & 21.3 \\
\hline Farmer Fertilization & 1.87 & 2.27 & 79.3 & 13.8 & 23.3 \\
\hline NP, MoA & 1.98 & 2.50 & 107.7 & 14.3 & 25.0 \\
\hline NK, MoA & 2.12 & 2.67 & 129.7 & 14.7 & 27.7 \\
\hline NPK, MoA & 2.91 & 2.80 & 138.0 & 17.0 & 31.0 \\
\hline NPK, based on Soil type & 3.14 & 3.00 & 183.7 & 19.0 & 35.0 \\
\hline NPK, based on Soil type + MN & 3.29 & 3.20 & 191.7 & 20.3 & 37.0 \\
\hline LSD $5 \%$ & 0.09 & 0.22 & 7.62 & 1.72 & 2.19 \\
\hline \multicolumn{6}{|c|}{ Second season $(2014 / 2015)$} \\
\hline Control (No added fertilizers) & 1.37 & 1.70 & 54 & 16 & 14 \\
\hline Farmer Fertilization & 1.73 & 1.77 & 67 & 17 & 15 \\
\hline NP, MoA & 1.83 & 2.23 & 79 & 18 & 15 \\
\hline NK, MoA & 2.01 & 2.37 & 85 & 19 & 16 \\
\hline NPK, MoA & 2.55 & 2.60 & 93 & 21 & 18 \\
\hline NPK, based on Soil type & 2.76 & 2.77 & 125 & 24 & 20 \\
\hline NPK, based on Soil type + MN & 3.01 & 2.80 & 136 & 28 & 24 \\
\hline LSD 5\% & 0.10 & 0.14 & 8 & 2 & 1 \\
\hline
\end{tabular}

TABLE 4. Yield and its components of wheat (Triticum sativum) as affected by different NPK levels and balanced fertilization

\begin{tabular}{|c|c|c|c|c|c|c|c|c|}
\hline Treatment & $\begin{array}{c}\text { Grain } \\
\text { yield } \\
\text { (ton/ha) }\end{array}$ & $\begin{array}{l}\text { Biologi- } \\
\text { cal yield } \\
\text { (ton/ha) }\end{array}$ & $\begin{array}{c}\text { Harvest } \\
\text { index } \\
(\%)\end{array}$ & $\begin{array}{l}\text { Spike } \\
\text { No. } / \mathrm{m}^{2}\end{array}$ & $\begin{array}{l}\text { Spike- } \\
\text { lets No./ } \\
\text { spike }\end{array}$ & $\begin{array}{c}\text { Spike } \\
\text { length } \\
(\mathrm{cm})\end{array}$ & $\begin{array}{c}100 \\
\text { grain } \\
\text { weight } \\
\text { (g) }\end{array}$ & $\begin{array}{c}\text { Plant } \\
\text { height } \\
(\mathrm{cm})\end{array}$ \\
\hline \multicolumn{9}{|c|}{ First season $(2013 / 2014)$} \\
\hline Control (No added fertilizers) & 2.29 & 7.37 & 31.07 & 191 & 13.67 & 8.83 & 3.76 & 60.3 \\
\hline Farmer Fertilization & 4.23 & 12.11 & $34.91^{`}$ & 271 & 16.65 & 9.50 & 3.97 & 73.7 \\
\hline NP, MoA & 4.58 & 12.84 & 35.66 & 278 & 17.67 & 10.20 & 4.22 & 85.0 \\
\hline NK, MoA & 4.93 & 13.56 & 36.33 & 285 & 19.31 & 10.77 & 4.27 & 101.0 \\
\hline NPK, MoA & 5.35 & 14.16 & 37.81 & 295 & 20.33 & 11.76 & 4.52 & 104.0 \\
\hline NPK, based on Soil type & 5.99 & 15.31 & 39.12 & 308 & 21.00 & 12.63 & 4.67 & 107.3 \\
\hline $\begin{array}{l}\text { NPK, based on Soil type }+ \\
\text { MN }\end{array}$ & 6.58 & 15.97 & 41.21 & 319 & 22.23 & 13.10 & 5.06 & 110.0 \\
\hline LSD 5\% & 0.18 & 0.45 & 0.56 & 4 & 1.03 & 0.39 & 0.12 & 4.80 \\
\hline \multicolumn{9}{|c|}{ Second season $(2014 / 2015)$} \\
\hline Control (No added fertilizers) & 2.22 & 7.2 & 30.7 & 187 & 11.3 & 8.3 & 3.95 & 59.4 \\
\hline Farmer Fertilization & 4.16 & 11.9 & 34.8 & 262 & 14.7 & 9.1 & 4.12 & 71.8 \\
\hline NP, MoA & 4.45 & 12.6 & 35.5 & 273 & 16.3 & 9.9 & 4.28 & 83.4 \\
\hline NK, MoA & 4.81 & 13.3 & 36.2 & 284 & 17.0 & 10.6 & 4.43 & 99.3 \\
\hline NPK, MoA & 5.27 & 14.0 & 37.7 & 290 & 18.3 & 11.3 & 4.57 & 103.3 \\
\hline NPK, based on Soil type & 5.93 & 15.2 & 38.9 & 301 & 18.7 & 12.3 & 4.85 & 106.3 \\
\hline $\begin{array}{l}\text { NPK, based on Soil type }+ \\
\text { MN }\end{array}$ & 6.47 & 15.7 & 41.1 & 314 & 20.3 & 13.3 & 5.11 & 108.7 \\
\hline LSD $5 \%$ & 0.17 & 0.52 & 0.51 & 4 & 1.2 & 0.5 & 0.05 & 4.8 \\
\hline
\end{tabular}


TABLE 5. Nutrient concentrations and protein in grain of wheat (Triticum sativum) as affected by different NPK levels and balanced fertilization

\begin{tabular}{|c|c|c|c|c|c|c|}
\hline \multirow{2}{*}{ Treatment } & \multicolumn{3}{|c|}{$\%$} & \multicolumn{3}{|c|}{ ppm } \\
\hline & $\mathbf{N}$ & Protein & $\mathbf{K}$ & $\mathrm{Fe}$ & Mn & $\mathbf{Z n}$ \\
\hline \multicolumn{7}{|c|}{ First season $(2013 / 2014)$} \\
\hline Control (No added fertilizers) & 1.69 & 10.57 & 0.40 & 27.3 & 17.0 & 18.3 \\
\hline Farmer Fertilization & 1.83 & 11.41 & 0.42 & 31.3 & 18.0 & 19.7 \\
\hline NP, MoA & 1.91 & 11.92 & 0.44 & 35.7 & 18.3 & 21.0 \\
\hline NK, MoA & 1.98 & 12.38 & 0.46 & 38.7 & 19.0 & 22.7 \\
\hline NPK, MoA & 2.13 & 13.34 & 0.48 & 41.7 & 20.3 & 23.7 \\
\hline NPK, based on Soil type & 2.24 & 14.00 & 0.50 & 55.0 & 23.2 & 25.3 \\
\hline NPK, based on Soil type $+\mathrm{MN}$ & $2 / 37$ & 14.79 & 0.55 & 89.7 & 28.0 & 29.0 \\
\hline LSD 5\% & 0.13 & 0.84 & 0.02 & 3.8 & 1.3 & 1.2 \\
\hline \multicolumn{7}{|c|}{ First season $(2014 / 2015)$} \\
\hline Control (No added fertilizers) & 1.60 & 10.00 & 0.41 & 23 & 17 & 14 \\
\hline Farmer Fertilization & 1.78 & 11.11 & 0.44 & 28 & 20 & 15 \\
\hline NP, MoA & 1.89 & 11.81 & 0.47 & 31 & 21 & 16 \\
\hline NK, MoA & 1.92 & 12.02 & 0.49 & 34 & 23 & 17 \\
\hline NPK, MoA & 2.03 & 12.67 & 0.52 & 38 & 25 & 20 \\
\hline NPK, based on Soil type & 2.20 & 13.73 & 0.55 & 48 & 28 & 30 \\
\hline NPK, based on Soil type + MN & 2.25 & 14.06 & 0.60 & 53 & 31 & 33 \\
\hline LSD 5\% & 0.08 & 0.52 & 0.03 & 2 & 2 & 3 \\
\hline
\end{tabular}

Nutrient concentrations in wheat straw

Table 6 shows that macro and micronutrients of wheat straw significantly increased by the different NPK levels and balanced fertilization as compared with both negative and positive controls.

The highest concentrations were achieved by applying NPK based on soil type + micronutrients foliar spray in both seasons. While the lowest increment in case of neglecting the negative and the positive controls was NP, MoA treatment. The treatments follow the same order of both flag leaf and wheat grain. Data indicated that applying the balanced fertilization through modifying the recommended NPK in combination with micronutrients increased the nutritional value of wheat straw which represents a very important fodder for animal feed, especially, in summer seasons.

\section{Conclusions}

Fertilizer recommendations of Ministry of Agriculture should be modified in case of there are some soil factors that limit the availability and absorption of nutrients. For example the present results of this study, fertilizers recommendation of MoA for wheat did not fit the required nutrients because of the the high $\mathrm{CaCO}_{3}$ content in the soil that limit the availability and absorption of nutrients such as high $\mathrm{CaCO}_{3}$ and $\mathrm{pH}$ and low organic matter.

Applying the modified fertilizers recommendation of $120 \mathrm{~N}: 45 \mathrm{P}_{2} \mathrm{O}_{5}: 48 \mathrm{~K}_{2} \mathrm{O} \mathrm{kg} /$ fed. + two times foliar spray of micronutrients at 40 and 60 days from sowing is recommended for wheat grown on calcareous soil for achieving high yield and best quality.

Acknowledgement: This paper is a part of the activities of the Egyptian-German Project. Micronutrient and Plant Nutrition Problems in Egypt implemented by NRC, Egypt. Authors wish to thank Prof. Dr. U. Schmidhlter Lehrstuhl fur Pflenzenernzhrung TU Weihensterphan for his advice and support. Financial support received from IPNI, U.S.A. Sincere Thanks to Prof. Dr. Al-Rusan, Jordan and IPNI, representative in MENA Region. 
TABLE 6. Nutrient concentrations in straw of wheat (Triticum sativum) as affected by different NPK levels and balanced fertilization

\begin{tabular}{|c|c|c|c|c|c|}
\hline \multirow{2}{*}{ Treatment } & \multicolumn{2}{|c|}{$\%$} & \multicolumn{3}{|c|}{ ppm } \\
\hline & $\mathbf{N}$ & $\mathbf{K}$ & $\mathrm{Fe}$ & Mn & Zn \\
\hline \multicolumn{6}{|c|}{ First season $(2013 / 2014)$} \\
\hline Control (No added fertilizers) & 0.39 & 1.09 & 40.0 & 9.7 & 9.0 \\
\hline Farmer Fertilization & 0.45 & 1.60 & 61.0 & 13.0 & 10.0 \\
\hline $\mathrm{NP}, \mathrm{MoA}$ & 0.49 & 2.00 & 74.3 & 13.7 & 10.7 \\
\hline NK, MoA & 0.51 & 2.40 & 85.0 & 14.3 & 13.0 \\
\hline NPK, MoA & 0.54 & 2.80 & 101.7 & 14.7 & 16.0 \\
\hline NPK, based on Soil type & 0.65 & 3.30 & 140.0 & 16.7 & 17.7 \\
\hline NPK, based on Soil type + MN & 0.72 & 3.40 & 164.3 & 20.7 & 20.0 \\
\hline LSD $5 \%$ & 0.04 & 0.22 & 5.38 & 1.95 & 1.21 \\
\hline \multicolumn{6}{|c|}{ First season $(2014 / 2015)$} \\
\hline Control (No added fertilizers) & 0.36 & 0.98 & 39 & 12 & 13 \\
\hline Farmer Fertilization & 0.41 & 1.43 & 48 & 15 & 14 \\
\hline NP, MoA & 0.46 & 1.70 & 53 & 17 & 15 \\
\hline NK, MoA & 0.49 & 2.10 & 80 & 18 & 16 \\
\hline NPK, MoA & 0.51 & 2.50 & 101 & 19 & 19 \\
\hline NPK, based on Soil type & 0.62 & 2.93 & 115 & 20 & 25 \\
\hline NPK, based on Soil type + MN & 0.67 & 3.10 & 120 & 22 & 33 \\
\hline LSD $5 \%$ & 0.03 & 0.22 & 5 & 2 & 3 \\
\hline
\end{tabular}

\section{References}

Abdel Aal, Sh.I., Shawky, M.E., Shain, R.S. (1990) Effects of land use on aggregation and carbonate mineralogy of some desertic calcareous soils of Egyptian Journal of Soil Science, 30, 43-58.

Abou-El Nour, E.A.A., El-Fouly, M.M. (2013) Increasing salinity tolerance of crops through approprite fertilizer use technologies. $19^{\text {th }}$ Annual AFA Fertilizer Forum "A Globle Fertilizer Platform" Feb. 23-28, 2013, Savoy Sharm ElSheikh Hotel- Egypt.

Alison, L.E., Moodle, C.D. (1965) Carbonate. In: "Methods of Soil Analysis", C.A. Black (Ed.), pp. 1379-1396. Amer. Soc. Agron. Inc., Madison, Wisconsin, USA.

Ankerman, D., Large, L. (1974) Soil and Plant Analysis, Technical Bulletin, A\&L Agricultural Laboratories Inc. USA, 82p.

Brady, N., Weil, R. (1999) "The Nuture and Properties of Soil". 12 $2^{\text {th }}$ ed. Prentice Hall, Upper Saddle River, New Jersey.
Chapman, H.D., Pratt, P.F. (1978) "Methods of Analysis for Soils, Plants and Water", Univ. of California, Dept. of Agric. Sci., USA, 320p.

Duncan, E.G., O’Sullivan, C.A., Roper, M.M., Palta, J., Whisson, K., Peoples, M.B. (2018a) Yield and nitrogen use efficiency of wheat increased with root length and biomass due to nitrogen, phosphorus, and potassium interactions. Journal of Plant Nutrition and Soil Science, 181(3), 364-73.

Duncan, E.G., O’Sullivan, C.A., Roper, M.M., Biggs, J.S., Peoples, M.B. (2018b) Influence of coapplication of nitrogen with phosphorus, potassium and sulphur on the apparent efficiency of nitrogen fertiliser use, grain yield and protein content of wheat. Field Crops Research, 226, 56-65.

El-Fouly, M.M., El-Sayed, A.A. (1997) Foliar fertilization: An environmentally friendly application of fertilizers. Dahlia Greidinger International Symposium on "Fertilization and Environment" 24-27 March, Haifa, Israel, Ed. John, J. pp. 346-357.

El-Fouly, M.M., Abou El-Nour, E.A.A., Shaaban, S.H.A., Zeidan, M.S. (2012) Effect of different 
levels of NPK and micronutrients fertilization on yield and nutrient uptake of maize plants. Journal of American Science, 8(8), 209-2014.

El-Saady, A.M., El-Fouly, M.M., Abou El-Nour, E.A.A. (2014) Soil testing as a base for modifying fertilizer recommendations of groundnut. International Journal ofAgriSciesnce, 4(6), 313-320.

Jackson, M.I. (1973) "Soil Chemical Analysis". Prentice Hall Inc. N. J., U. D. A. Jones, Jr J Benton, Benjamin Wolf, and Harry A.

Kumar, V., Naresh, R.K., Kumar, S., Kumar, S., Kumar, A., Gupta, R.K., Rathore, R.S., Singh, S.P., Dwivedi, A., Tyagi, S., Mahajan, N.C. (2018) Efficient nutrient management practices for sustaining soil health and improving rice-wheat productivity: A review. Journal of Pharmacognosy and Phytochemistry, 7, 585-597.

Lindsay, W.L., Norvell, W.A. (1978) Development of a DTPA icronutrients soil test. Soil Science Society of America Journal, 42, 421-428.

Ma, T.S., Zuazage, C. (1942) Micro-Kjeldahl determination of nitrogen a new indicator and an improved repaid method. Industr. Eng. Chem. Anal. Ed. 14, 280p.

Malghani, A., Malik, A.U., Sattar, A., Hussain, F. Abbas, G., Hussain, J. (2010) Response of growth and yield of wheat to NPK fertilizer. Science International (Lahore), 24(2), 185-189.

Olsen, S.R., Colu, S.V., Watanabe, F.S., Dean, L.A. (1954) Estimation of available phosphorus in soil by extraction with bicarbonate. U. S. Dept. Circ. 939p.

Salim, N.A., Raza, A. (2020) Nutrient use efficiency (NUE) for sustainable wheat production:a review. Journal of Plant Nutrition, 43(2), 297-315.

Snedecor, G.W., Cochran, W.G. (1990) "Statistical Methods" $7^{\text {th }}$ ed. Iowa State Univ. Press, Ames, Iowa, U.S.A.

Soh, K.G. (1998) Global Fertilizer usage and its demand outlook. AFA Fourth International Annual Conference, Cairo, 17-19 Feb., 1998- Cairo, Egypt, pp. 1-12.

Vitousek, P.M., Naylor, R., Crews, T., David, M.B., Drinkwatter, L.E., Holland, E., et al. (2009) Nutrient imbalances in agricultural development. Science, 324(19), 1519-1520.

Wahba, M.M., Labib, Fawkia, Zaghloul, A. (2019) Management of calcareous soils in arid regin. International Journal of Environmental Pollution and Environmental Modelling, 2(5), 248-258.

Walkely, A., Black, I.A. (1934) An examination of the Degtjareff method for determining soil organic matter, and a proposed modification of the chromic acid titration method. Soil Science, 37, 29-38.

Zheng, W., Zhiguang, L., Min, Z., Yuefeng, S., Qiang, Z., Yunbao, S., et al. (2017) Improving crop yields, nitrogen use efficiencies, and profits by using mixtures of coated controlled-released and uncoated urea in a wheat-maize system. Field Crops Research, 205, 106-115. 


\section{هل يمكن زيادة انتاجية قمح الخبزالنامى تحن ظروف الاراضى الجيريةعن طريق تعديل

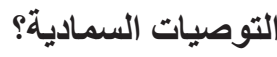

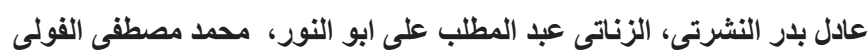

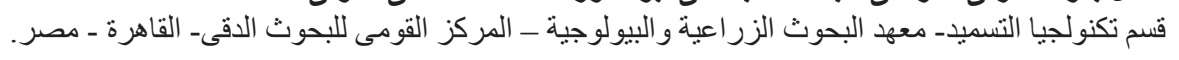

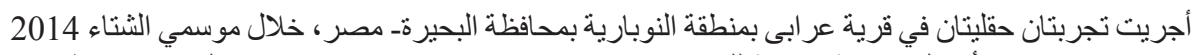

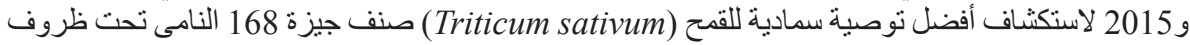

التربة|الجيرية حيث ان إنتاجية القصح تكون منخفضة جدًا عند زر اعته في ظل ظروف هذه التربة. تم اختبار سبعة

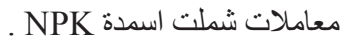

وأشارت النتائج إلى أن جميع معاملات NPK أظهرت تأثيرات إيجابيةعلى جميع المتغيرات المدات المدروسة

بالمقارنة مع معاملة عدم اضافة الى أسمدة أو بالمقارنة مع الاضافات السمادية التى تتم عن طريق المز التهارع.

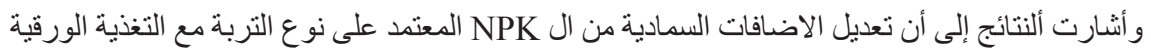

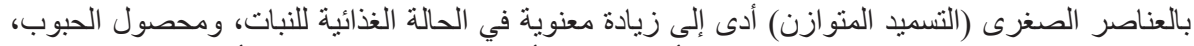

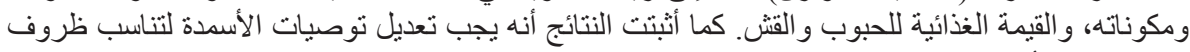

التربة لتحقيق أقصى قدر من إنتاجية المحاصيل. 